\title{
Despre procesul de formare a ecosistemului forestier
}

\author{
N. Doniță
}

Doniță N., 2020. About shaping the forest ecosystem. Bucov. For. 20(1): 89-91.

Abstract. The paper summarizes the two stages of the forest ecosystem formation: (i) the establishing phase of the primary producers, which takes place beneath the tree canopy, as a consequence of having produces large amounts of seeds; (ii) the phase of spontaneous immigration of consumers and decomposers towards these massifs, which brings about the formation of the biocenosis and the forest ecosystem. This second stage is documented by thorough researchers carried out in experimental plantations installed in steppe, forty years after.

Keywords: forest ecosystems, stages, formation.

Author. Nicolae Doniță (secretariat@asas.ro) - The Academy of Agricultural and Forestry Sciences „Gheorghe Ionescu-Şişeşti” (A.A.F.S.), B-dul. Marasti Nr. 61, Sector 1, Bucuresti, Cod 011464.

Manuscript: received May 20, 2020; revised May 30, 2020; accepted Juny 18, 2020; online first August 20, 2020.

În îndelungata evoluție a lumii vii s-au format trei mari categorii ecologice de specii: producătoare de biomasă și necromasă (plantele), consumatoare de biomasă și producătoare de necromasă (animalele, organismele inferioare), consumatoare și descompunătoare de necromasă (ciuperci, bacterii, microinsecte).

Speciile din aceste categorii nu pot exista separat pentru că cele producătoare s-ar îngropa în necromasa produsă, cele consumatoare nu ar avea hrană iar cele descompunătoare nu ar avea hrană şi material organic de descompus (Doniţă și Godeanu, 2019).

Şi este logic că pentru a se forma o biocenoză și un ecosistem este absolut necesara existență prealabilă a speciilor producătoare, principala resursă de existență a celor consumatoare și descompunătoare.

Referindu-ne la formarea ecosistemului forestier am prezentat, acum 13 ani, într-o scur- tă lucrare (Doniță, 2006) principalele cauze care arată de ce și unde arborii cresc în masiv și se creează astfel condiţii pentru constituirea ecosistemului forestier.

Aceste cauze sunt: (i) tendinţa organismelor din fiecare specie, deci și a arborilor, de a genera cât mai mulți urmași, ca o asigurare pentru perpetuarea speciei și (ii) caracterul limitat al mediului abiotic al uscatului, atât ca spațiu cât și ca resurse abiotice vitale din acel spațiu necesare creșterii arborilor, ca plante verzi producătoare de biomasă din elemente abiotice.

Și am arătat că, mulțimea mare de semințe produse de arbori la fructificații abundente, determină o bogată însămânțare atât a terenului ocupat de pădure dar și a terenurilor libere învecinate, adică creează chiar de la început condiții pentru formarea unui masiv strâns din puieții răsăriți. Și am dat câteva exemple des- 
pre numărul mare de semințe (fructe) produse în anii de fructificație abundentă la gorun, fag, molid (de ordinul a câtorva sute la metru pătrat). Chiar dacă nu răsar toate semințele și dintre puieții răsăriți majoritatea dispare în primii ani, rămân totuşi destui puieți pentru a constitui masivul.

Dar am arătat și faptul că creșterea în masiv a arborilor are loc numai în climate favorabile existenței și dezvoltării lor normale și a fructificaţiei lor abundente. În climate secetoase sau reci, arborii nu mai cresc în masiv ci izolat sau în grupe mici, printre arbuști sau ierburi. În climate extrem de uscate sau foarte reci arborii nu se mai întâlnesc.

Și în concluzie am arătat că “Așadar creșterea arborilor în masiv este un fenomen natural inerent, în climate favorabile, din cauza numărului mare de descendenți care trebuie să se dezvolte într-un mediu abiotic limitat". Şi în asemenea climate, pădurea se reproduce acolo unde există dar și ocupă orice suprafață liberă. Și avem destule exemple în acest sens când terenuri abandonate de agricultură se împăduresc spontan.

Dar odată format masivul de arbori (deci de producători) cum se constituie de fapt întreaga biocenoză de pădure și întregul ecosistem, atât de complex prin compoziția și funcționarea lui?

La această întrebare ne dă un răspuns o cercetare complexă efectuată în anii 1990-1992, în culturile experimentale de arbori și arbuști, instalate în anii 1946-1950, în stațiunea Bărăgan, a Institutului de Cercetări și Amenajări Silvice, în climat și pe soluri de stepă (Doniță et al., 2011).

$\mathrm{Au}$ fost cercetate culturile de arbori și arbuști sub formă de mici masive și perdele de protecție compuse din specii de foioase (stejari, frasini, tei, arțari, ulm de turkestan, salcâm, păr pădureț, vișin turcesc, lemn câinesc, păducel, sânger, caragana) și două specii de răşinoase (molid, larice).

S-a făcut inventarierea arboretelor, stabilindu-se indicii cantitativi ai populațiilor de arbori ca și biomasa arbuștilor și ierburilor. S-a 90 stabilit și necromasa (litiera) pe două componente - nedescompusă și în curs de descompunere. S-au determinat speciile de macro și micromicete ca și acarienii din litieră și sol, insecte de coroane și tulpină, păsările și mamiferele. De asemenea s-au investigat climatul interior al culturilor și modificările induse în solurile de sub culturi.

Lăsând la o parte datele despre arborii și arbuștii cultivați care au funcția de producători principali de biomasă și necromasă, să ne referim la alţi producători (ierburile), la consumatorii și la descompunătorii care s-au găsit în culturi după 40 de ani de la instalarea lor și care pe diferite căi au populat culturile.

S-au găsit 24 de specii de ierburi de pădure, 103 specii de macromicete, 84 specii de micromicete și zeci de specii de acarieni în litieră și sol, 1250 specii de insecte de coroană și tulpină, 30 specii de păsări, 7 specii de mamifere. Stratul de litieră avea 3-10 tone/ha, din care 20\% litieră nedescompusă și $80 \%$ litieră în diverse stadii de descompunere.

Cercetările asupra climei interne din culturi şi a acidității, compoziţiei chimice și a umidității solurilor au evidențiat influențe modificatoare a culturilor după 40 de ani de existență.

Prin această cercetare complexă s-a pus în evidență cum, într-un răstimp destul de scurt, de numai 40 de ani, a început să se formeze o adevărată biocenoză forestieră cu componentele ei obligatorii: producătorii (arborii și arbuștii introduși de om), dar și o mulțime de consumatori și descompunători veniți spontan pe diferite căi.

Semnificativ este faptul că și în regiuni în care sunt puține păduri sau acestea lipsesc, au loc totuşi imigrări masive de consumatori și descompunători specifici pădurii. Este urmarea numărului mare de descendenți produși de organisme și adaptările speciale pe care le au pentru răspândirea în spaţiu.

A început să funcționeze procesul ecosistemic de producere, consum şi descompunere a biomasei și necromasei evidenţiat prin datele asupra biomasei și necromasei produse de arbori și arbuști prin activitatea consumatorilor, 
care s-a manifestat inclusiv și prin înmulțiri în masă a insectelor defoliatoare și prin activitatea ciupercilor și a insectelor, indicată de proporția mare a litierei aflate în diverse faze de descompunere.

Iar datele obținute prin cercetări microclimatice și edafice au arătat că biocenozele în formare au influenţat sesizabil mediul abiotic, prin crearea microclimatului tipic de pădure și modificări ale regimurilor de apă, de reacție și de troficitate a solurilor.

Deci, se poate afirma, pe baza acestor cercetări, că simpla prezență a unor producători (în speță arbori și arbuşti) într-un teren (stațiune) declanșează procesul de formare a unei biocenoze prin imigrarea spontană a consumatorilor și descompunătorilor. Iar relațiile ce se stabilesc între aceasta și cu mediul abiotic, prin fluxurile și circuitele materiale, duc la formarea ecosistemului.

De altfel, în cazul regenerării naturale a arboretelor, provocate de om, are loc același proces de reproducere a întregii biocenoze și a ecosistemului pe baza semințișului ce s-a format, în care pătrund, treptat, toate celelalte componente ale biocenozei din pădurile învecinate.

În concluzie, se poate afirma că un ecosistem forestier se poate constitui în orice climat favorabil pădurii fie prin regenerarea unor generații de arbori, acolo unde au existat, fie într-un teren liber, din cauza numărului mare de semințe și apoi de puieți, care răsar pe o suprafață de o anumită întindere limitată.

O dată instalați arborii și alte plante producătoare de biomasă și necromasă, imigrează spontan toate celelalte componente ale bioce- nozei forestiere și se declanșează procesul de formare a biocenozei, ia naştere și procesul de producere, consum și descompunere a materiei organice formându-se fluxurile și circuitele de elemente abiotice vitale între biocenoză și habitat, formându-se astfel ecosistemul forestier.

Trebuie însă precizat că un asemenea proces de formare a ecosistemului forestier are loc complet numai în cazul când, în regiunea respectivă, se instalează natural sau artificial arbori autohtoni la care sunt coadaptate toate speciile de alte plante, ciuperci, animale și microorganisme care compun biocenozele naturale și care vor forma noua biocenoză.

Dacă se fac culturi de arbori alohtoni, aduși din alte regiuni, lipsind celelalte specii cu care acești arbori sunt asociați în locul lor de origine, se va forma o biocenoză incompletă din specii locale dar cu amplitudine ecologică mare care le permite o conviețuire cu arborii respectivi. Este de exemplu cazul culturilor de salcâm, de stejar roșu, etc.

\section{Bibliografie}

Doniță, N., 2006: Elemente pentru o teorie a genezei pădurii. Rev. Păd. 121, 38-40.

Doniță, N., Lupe, I., Bândiu, C., Ceianu, I., Fodor, E., Gafta, D., Neșu, I., Tutunaru, V., Roșu, C., Surdu, A., Ionescu, M., Timotei, C., Palifron, V., Ivan, D., Parascan, D., Simon, D., Honciuc, V., Bâzâc, Gh. 2011: Culturi forestiere experimentale din stațiunea Bărăgan. Ed. Silvică, București 161 p.;

Doniță, N., Godeanu, S., Sfetea, R., 2019: Population, Species, Biocenosis. An integrating vision. Lambert Acad. Press. 109 p. 